\title{
25-Hydroxycholecalciferol levels in a representative sample of children and young adolescents from the Ikwerre-speaking Local Government Areas of Rivers State, Nigeria
}

\author{
OrluweneChituru Godwill ${ }^{1}$, Opurum Hamilton ${ }^{2}$ \\ B.Med. Sci; MBBS; FMCPathB.Sc, AIMLS, MSC, Ph.D \\ ${ }^{I}$ Department of Chemical Pathology, University of Port Harcourt Teaching Hospital, Port Harcourt, Nigeria \\ ${ }^{2}$ Department of Chemical Pathology, University of Port Harcourt, Port Harcourt Nigeria.
}

\begin{abstract}
Adequate vitamin D status is important for bone growth and mineralization and has been implicated in the regulation of autoimmunity, metabolic function and cancer prevention. There are no reports of population-based studies on the vitamin D status of Rivers State youth in Nigeria, a population where mandatory fortification of foods is currently advocated.

We measured 25-hydroxycholecalciferol [25(OH)D], the best indicator of vitamin D status, in a postprimary school-based cross-sectional sample of representative Rivers State youth $(n=1120)$ ages 10, 15, and 20 living in the Ikwerre-speaking local government areas (LGAs). Blood samples were collected from February to July 2009. We defined 25(OH)D deficiency as $\leq 27.5 \mathrm{nmol} / \mathrm{L}$, hypovitaminosis as $\leq 37.5 \mathrm{nmol} / \mathrm{L}$, and optimal as $>75 \mathrm{nmol} / \mathrm{L}$.

More than $95 \%$ of youth in each age and sex group had suboptimal $25(\mathrm{OH}) \mathrm{D}$ concentrations. The prevalence of $25(\mathrm{OH}) D$ deficiency increased with age in both sexes $(P<0.001)$. It was $2 \%, 4 \%$ and $13 \%$ in 10, 15, and 20-year-old boys and 2\%, 9\% and 12\% in 10, 15, and 20-year-old girls. Girls with higher body mass index and girls from households with lower income had lower 25(OH)D concentrations. These effects were not found in boys.

Inadequate vitamin D status is a potentially serious public health problem among children and young adolescents in Rivers State. This result calls for renewed efforts to ensure adequate vitamin D intake among growing children and adolescents.
\end{abstract}

Keywords: Children, 25-hydroxycholecalciferol, Nigeria, Rivers-State, vitamin-D, Young-adolescents.

\section{Introduction}

Vitamin D facilitates the intestinal absorption of calcium and phosphorus and plays an important role in bone mineralization [1]. It follows that maintainingoptimal 25-hydroxycholecalciferol [25(OH) D] concentrations is particularly important during the growth period in children and adolescents, when much of adult bone mass is established [2]. Vitamin D is believed to exert physiological effects beyond the skeletal system [3]. Indeed, the identification of vitamin D-specific nuclear receptors, in a number of tissues, indicates that this hormone plays a role in several physiological processes including cancer prevention [4], immune regulations [5], and glucose homeostasis [6].

Ultraviolet activation of 7-dehydrocholesterol in the epidermis is the predominant source of cholecalciferol or vitamin $\mathrm{D}_{3}$ [7]. This secosteroid is then transported to the liver where it is hydroxylated to yield $25(\mathrm{OH}) \mathrm{D}$. when dietary calcium intake is low, the parathyroid glands respond to minute decreases in ionized serum calcium by releasing parathyroid hormone (PTH). Parathyroid hormone, in turn, regulates the final hydroxylation of vitamin $\mathrm{D}$ in the renal mitochondria, yielding the biologically active hormone, 1- $\alpha, 25-$ dihydroxycholecalciferol [8]. Activevitamin D has three target tissues relevant to calcium metabolism. First, active vitamin $\mathrm{D}$ initiates the breakdown of bone tissue, releasing calcium into the serum; second, it increases the absorption of dietary calcium in the gut; finally, active vitamin D increases the reabsorption of calcium in the distal tubule of the kidney [3].

Cutaneous vitamin D synthesis is season dependent. During the rainy seasons (with reduced periods of sunlight) and particularly (as in Nigeria) from February to July, vitamin D production endogenously is reduced and the body then depends on exogenous sources in fortified foods or supplements [9]. The 1997 Institute of Medicine guidelines for dietary intake of vitamin D were meant to prevent the seasonal increase in PTH associated with lower vitamin D status, assuming little or no cutaneous production of vitamin D [10]. Increased plasma concentration of PTH is a marker of bone remodeling. Consistently increased concentrations of PTH are associated with an increase in risk for osteoporosis in later life [11].

Several studies have documented vitamin D deficiency and hypovitaminosis from populations inhabiting a wide range of climatic conditions, including male adolescents in Paris [12], white adolescent girls 
in Maine [13], inner-city adolescent girls in Manchester, UK [14], and school-aged youth from Lebanon [15]. Mandatory fortification of staple foods does exist in the US, Canada, and Finland. Fortification have been shown to increase vitamin D intake consistent with dietary intake guidelines proposed by the Institute of Medicine [16]. An expert consensus among vitamin D researchers has stated that current levels of food fortification are inadequate to support optimal vitamin D status in adults [17]. In youth, little is known regarding the effectiveness of fortification in mitigating vitamin D deficiency or supporting optimal vitamin D status. Further, there are no reports of large population-based studies on the vitamin D status of youth in Rivers State, Nigeria-a region in Nigeria where mandatory fortification of staple foods with vitamin D is strongly advocated.

25-hydroxycholecalciferol [25(OH)D] is widely recognized as the best indicator of vitamin D status [7] and so in this study we assessed the vitamin D status of a representative sample of children and youngadolescents from the Ikwerre-speaking local government areas of Rivers State, Nigeria by measuring samples collected from February to July (the period when skin vitamin D synthesis is expected to be). We also tested the association or influence of age, sex, adiposity and sociodemographic variables on 25(OH)Dconcentrations.

\section{Subjects and methods}

The study population comprised children and young-adolescents who participated in the Ikwerrespeaking Local Government Areas Health Survey (ISLGAHS), a post-primary school-based survey conducted between February and July, 2009. We used a cluster sampling design to draw representative samples of youth from 15 post-primary schools in the four Ikwerre-speaking Local Government Areas of Rivers State, of youth ages 10, 15 and 20 years. Questionnaire and anthropometric data were available for 1200 youth distributed as 400 each of eligible $10^{-}, 15^{-}$, and 20years-old. Out of this total number total number, 90\% (360), 93\% (372) and 96\% (388) of 10-, 15- and 20-year-olds actually participated in the final stages of the study and provided a fasting blood specimen. Thus, a total 1120 (93\%) blood specimens were available for analysis. Eighty (80) were excluded because parents refused consent for obtaining blood specimen from their children for the study or because the specimens obtained were of insufficient quantity for analysis of $25(\mathrm{OH}) \mathrm{D}$. There were no differences in sex, body mass index (BMI) z score, or parental income among youth for whom blood samples were studied as against those not studied. The Local Government ethics review board of Rivers State approved this study.

Written informed consent and assent were obtained from the parents/guardians and participants respectively. Height was measured to the nearest $0.1 \mathrm{~cm}$ at maximal inspiration using a measuring tape and a triangular level. Weight was measured with light in-door clothing with shoes removed. BMI was calculated by dividing the weight (in $\mathrm{kg}$ ) by the square of the height (in meter) $\left(\mathrm{kg} / \mathrm{m}^{2}\right)$. We categorized youth as overweight if their BMI was $\geq 85$ th and $<95$ th or obese at $\geq 95$ th percentile values for their sex and age according to the 2000US CDC growth charts [18]. We categorized household income as high, middle and low income based on total income and number of persons living in the household; household income was coded as 'no reply' if parents did not respond to the income question. We used the location of each of the schools used for this study as a proxy for the location of the participants' residences, and schools were classified as rural or urban based on the National population commission classification in Nigeria.

Venous blood was collected after an overweight fast between 0800 and 1000 hours in EDTA specimen collection tubes and placed on ice. Specimens were centrifuged on site at 3000 revolutions/minute within $45 \mathrm{~min}$ of collection, transported on dry ice, and stored at $-70^{\circ} \mathrm{C}$. In August, 2009, we used competitive immunoassay (Radioimmunoassay) for the quantitative determination of plasma 25(OH)D (Immunodiagnostic system limited). The interassay coefficient of variation (CV) was $5.9 \%$ at $30.6 \mathrm{nmol} / \mathrm{L}$ and $6.0 \%$ at $109.4 \mathrm{nmol} / \mathrm{L}$ [19,20].

We used 3 cutoffs to describe vitamin D status: deficiency, hypovitaminosis and optimal. In the absence of rickets or osteomalacia, there are no outcome-based criteria to define vitamin D deficiency, though it has been proposed that paediatric vitamin D deficiency can be defined as plasma $25(\mathrm{OH}) \mathrm{D}<25-30 \mathrm{nmol} / \mathrm{L}$ [21]. The Institute of Medicine defines vitamin $\mathrm{D}$ deficiency as $25(\mathrm{OH}) \mathrm{D} \leq 27.5 \mathrm{nmol} / \mathrm{L}$ [22]. For hypovitaminosis $\mathrm{D}$, we used a literature-reported cutoff for $25(\mathrm{OH}) \mathrm{D}$ of $\leq 37.5 \mathrm{nmol} / \mathrm{L}$ [23]. The value for optimal $25(\mathrm{OH}) \mathrm{D}$ concentrationswas $>75 \mathrm{nmol} / \mathrm{L}$, a value thought to be consistent with both improved bone health [24] and other health outcomes [25] in adults.

\section{Statistical Analysis}

We computed age-and sex-specific $\mathrm{z}$ scores for BMI using a SAS program developed by the CDC based on the 2000 US CDC growth charts [26]. To take the complex study design into account, sampling weights and clustering effects by school were estimated and incorporated into computations of prevalence, percentile values, and $95 \%$ confidence intervals (95\% CIs). We used the non-parametric method developed by Huston [27] to estimate percentiles and their CIs. Because of low observed frequencies, we calculated exact binomial 95\% CIs [28] for the prevalence of the 3 concentrations of $25(\mathrm{OH}) \mathrm{D}$. We tested differences in the prevalence between sexes and across ages using a likelihood ratio test in a generalized logistic model to take the clustering effect within school into account. We tested the association between mean $25(\mathrm{OH}) \mathrm{D}$, sex, and age in 
univariate regression analysis. We used hierarchical maximum likelihood regression to estimate regression coefficients for univariate and multivariate associations. Explanatory variables were treated as fixed effects, and clustering between individuals in the same school was treated as a random effect. We stratified analysis by sex because of a significant age $\mathrm{x}$ sex interaction $(\mathrm{P}<0.001)$ in a model including sex, age, BMI $\mathrm{z}$ score, month of blood draw, parental income, and location of residence. Statistical analysis were performed with SAS version 9.1 (SAS Institute, Inc.).

\section{Result}

Salient characteristics of the participants are shown in Table 1. Majority of the blood specimen (81\%) were drawn between February and April. Plasma 25(OH)D concentrations ranged from 12.5 to $118.7 \mathrm{nmol} / \mathrm{L}$. Mean age- and sex-specific plasma 25(OH)D concentrations and percentile values are presented in Table 2 . With the exception of 20-year-old girls, the value of the 95th percentile in each age and sex group was below the optimal concentration of $75 \mathrm{nmol} / \mathrm{L}$. We observed no significant differences in mean $25(\mathrm{OH}) \mathrm{D}$ between sexes $(\mathrm{P}$ $=0.6)$. In both sexes combined, 15 -and 20-year-olds had significantly lower mean 25(OH)D than 10-year-olds $(43.1 \mathrm{nmol} / \mathrm{L}$ versus $49.4 \mathrm{nmol} / \mathrm{L})(\mathrm{P}<0.001)$.

More than $11 \%$ of 20 -year-olds were $25(\mathrm{OH}) \mathrm{D}$ deficient (Table 3). The prevalence of deficiency increased significantly with age in both sexes. As many as 37\% of 20-year-old boys and 30\% of 20-year-old girls had $25(\mathrm{OH}) \mathrm{D}$ concentrations consistent with hypovitaminiosis. The prevalence of hypovitaminosis increased significantly with age in both sexes. $25(\mathrm{OH}) \mathrm{D}$ concentrations were not optimal in the vast majority of children and young adolescents.

Girls in the low category of household income had significantly lower 25(OH)D than those in the high income category after adjustment for age, month of specimen collection, area of residence, and BMI z score (Table 4).

Boys and girls in this study with no reply in terms of parental/guardian income level had the lowest concentrations of $25(\mathrm{OH}) \mathrm{D}$. In contrast to boys, BMI z score was significantly associated with $25(\mathrm{OH}) \mathrm{D}$ concentrations in girls: a one standard deviation (ISD) increase in BMI was associated with a $1.8 \mathrm{nmol} / \mathrm{L}$ decrease in $25(\mathrm{OH}) \mathrm{D}$. There was no association in either sex between plasma $25(\mathrm{OH}) \mathrm{D}$ and month of specimen collection or residence in rural or urban setting.

\section{Discussion}

Our study is the first to examine vitamin D status during the rainy months in a representative population-based sample in Rivers State, Nigeria. This study revealed a relatively high prevalence of $25(\mathrm{OH}) \mathrm{D}$ deficiency, in particular among 20-year-old boys and girls. We did not detect any differences in $25(\mathrm{OH}) \mathrm{D}$ concentrations between specimens collected in February to April and May to July, suggesting that the period of deficiency or hypovitaminosisextended all through the rainy months.

Our results concur with those of others to suggest that vitamin D deficiency and hypovitaminosis D are widespread among children and adolescents during periods of relative absence of sunlight. For example, Das et al. [14] reported a mean serum $25(\mathrm{OH}) \mathrm{D}$ concentration of $37.3 \mathrm{nmol} / \mathrm{L}$ at the end of May in white girls from Manchester, UK. A population-based sample of adolescent girls from Denmark, Finland, Ireland and Poland taken during February and March reported a median serum 25(OH)D of 29.4nmol/L [29]. Similar findings were reported among youth in Philadelphia [30] and New Zealand [31]. In Canadian children, rickets is an ongoing concern. Ward et al. [32] reported 104 cases of vitamin D-deficient rickets between July 2002 and June 2004 (incidence rate 2.9/100,000). Affected children in this study had a mean age of 1.4 years, and many were dark skinned or residing in Northern Canada. Both skin colour and living in the North have been associated with decreased cutaneous synthesis of vitamin D [3].

A 3-year prospective study of 171 peripubertal Finnish youth reported that baseline vitamin D deficiency [defined as $25(\mathrm{OH}) \mathrm{D} \leq 20 \mathrm{nmol} / \mathrm{L}$ ] in a context of high dietary calcium intake $(1575 \mathrm{mg} /$ day) was associated with a decrease in bone mineral content of the lumbar spine 3 years later in older girls [33]. Furthermore, recent findings from observational and randomized trials suggest that optimal $25(\mathrm{OH}) \mathrm{D}$ and adequate dietary calcium intake are important for the prevention of cancer [4], type 1 diabetes [34], type 2 diabetes [35], and other health outcomes [3].

Similar to a study of New Zealand youth [31], our analysis showed an inverse association between $25(\mathrm{OH}) \mathrm{D}$ concentrations and body weight in girls. The sequestration of vitamin $\mathrm{D}$ into adipose tissue is thought to explain this association [36]. Our findings that girls of low socioeconomic status had lower concentrations of $25(\mathrm{OH}) \mathrm{D}$ was not consistent with a report from Philadelphia in which caregiver education and annual income were used as measures of socio-economic position [30]. Youth whose parents did not respond to the question on income had the lowest concentrations of $25(\mathrm{OH}) \mathrm{D}$. Non-response (no reply) is generally thought to be most common among individuals in highest and lowest socioeconomic position [37]. Further research will be needed to explore the association between $25(\mathrm{OH}) \mathrm{D}$ concentrations and socioeconomic status. 
There is no widely agreed consensus on the threshold to define vitamin D deficiency in paediatricpopulations. We elected therefore to use multiple cut points and present selected percentile values to facilitate comparisons with other studies. We collected our specimens between February and July, 2009 and carried out analysis of $25(\mathrm{OH}) \mathrm{D}$ in all the specimens collected by August, 2009. There is no worry about the stability of $25(\mathrm{OH}) \mathrm{D}$ as this question does not arise and $25(\mathrm{OH}) \mathrm{D}$ has been shown to be stable even under repeated freeze/thaw cycles [38].

We did not directly collect information on sun exposure and dietary sources of vitamin D. One limitation of our assay method (Immunodiagnostic systems Radioimmunoassay) is underestimation of vitamin $\mathrm{D}_{2}$. According to the manufacturers report, the assay detects only $75 \%$ of this analyte.

\section{Conclusion}

We have found in our study that, 25(OH)D deficiency and hypovitaminosis were highly prevalent in children and young adolescents living in Rivers State, Nigeria during the rainy months of 2009-a population for whom fortification of staple foods is strongly advocated.

No recent representative surveys of vitamin D status in youth are available in Rivers State. This lack calls for urgent monitoring of indicators of vitamin D status in other states of Nigeria. Viet et al. [17], in their editorial, have recently called for international agencies to reassess the dietary recommendations for vitamin $\mathrm{D}$ to ensure optimal concentrations of $25(\mathrm{OH}) \mathrm{D}$. The findings of our study in a developing country (Nigeria) strongly support such a plea.

\section{Acknowledgments}

We are grateful to the four Ikwerre-speaking local government council chairmen in Rivers State for sponsoring this study. We are also thankful to the participants and their parents/guardians for their co-operation.

\begin{tabular}{|c|c|c|}
\hline \multicolumn{3}{|c|}{ Table 1: Some characteristics of the study participants } \\
\hline Characteristics & Boys, $\%(n)$ & Girls, $\%$ (n) \\
\hline Ag & & \\
\hline 10 & $31.1(186)$ & $30.1(181)$ \\
\hline 15 & $33.1(198)$ & $32.9(198)$ \\
\hline \multirow{2}{*}{\multicolumn{3}{|c|}{ Household income }} \\
\hline & & \\
\hline High & $14.9(89)$ & $13.5(81)$ \\
\hline Middle & $60.4(361)$ & $62.3(375)$ \\
\hline Low & $10.0(60)$ & $10.6(64)$ \\
\hline Noreply & $14.7(88)$ & $13.6(82)$ \\
\hline \multicolumn{3}{|l|}{ Area of residence } \\
\hline Urban & $55.4(331)$ & $56.1(338)$ \\
\hline \multirow{2}{*}{\multicolumn{3}{|c|}{ BMI Category* }} \\
\hline & & \\
\hline Normal weight & $76.4(457)$ & $77.1(464)$ \\
\hline Overweight & $13.0(78)$ & $14.3(86)$ \\
\hline Obese & $10.6(63)$ & $8.6(52)$ \\
\hline \multicolumn{3}{|l|}{ Month of specimen collection } \\
\hline February-April & $81.1(485)$ & $80.9(487)$ \\
\hline May-July & $18.9(113)$ & $19.1(115)$ \\
\hline \multicolumn{3}{|l|}{ Note: } \\
\hline \multicolumn{3}{|c|}{$\begin{array}{l}\text { BMI }=\text { Body Mass Index } \\
{ }^{*} \text { Normal weight is defined as } \leq 85^{\text {th }} \text { percentile, overweight is the } 85 \text { th to } 95 \text { th percentile, and obese is } \geq 95 \text { th } \\
\text { percentile of the } 2000 \text { US-CDC growth charts [18]. }\end{array}$} \\
\hline
\end{tabular}




\begin{tabular}{|c|c|c|c|c|c|c|}
\hline \multicolumn{7}{|c|}{ Table 2: Percentile values and mean plasma $25(\mathrm{OH}) \mathrm{D}(\mathrm{nmol} / \mathrm{L})$ by sex and age* } \\
\hline & \multicolumn{3}{|c|}{ Boys } & \multicolumn{3}{|c|}{ Girls } \\
\hline & 10vears & 15 vears & 20 vears & 10year & 15years & $\overrightarrow{20 \text { years }}$ \\
\hline$n$ & 186 & 198 & 214 & 181 & 198 & 223 \\
\hline $\begin{array}{l}\text { Percentile } \\
\text { 5th }\end{array}$ & le $33.5(28.8-35.4)$ & $28.2051-326)$ & $21.8(183-257)$ & $28.1(27.2-34.5)$ & $23.1(20,7-27-4)$ & $22.7(20.6-26.9)$ \\
\hline 25th & $41.5(40.0-44.3)$ & $34.2(33.1-37.3)$ & $30.2(28.5-32.8)$ & $40.4(39.5-43.1)$ & $31.7(31.1-35.7)$ & $31.2(29.3-33.8)$ \\
\hline 50th & $50.7(47.5-51.9)$ & $43.3(40.1-44.8)$ & $40.3(37.6-42.8)$ & $47.2(44.9-49.7)$ & $38.7(36.5-40.9)$ & $43.8(40.1-46.7)$ \\
\hline 75th & $55.9(55.1-58.5)$ & $48.6(48.7-51.7)$ & $49.7(48.2-51.8)$ & $53.1(52.3-55.7)$ & $45.7(44.4 .47 .6)$ & $54.7(50.3-56.5)$ \\
\hline 95th & $71.8(68.4-75.4)$ & $61.3(56.3-66.1)$ & $67.3(63.4-71.6)$ & $66.7(63.1-69.6)$ & $58.8(56.5-64.2)$ & $79.5(74.2-90.3)$ \\
\hline Mean & $51.48(48.10-52.9)$ & $43.4(40.46-46.3)$ & $42.1(39.7-45.4)$ & $47.3(45.5-49.9)$ & $40.2(38.1-41.8)$ & $46.7(42.8-50.3)$ \\
\hline
\end{tabular}

\begin{tabular}{|c|c|c|c|c|c|}
\hline \multicolumn{6}{|c|}{ Table 3: Participants (Expressed in percent) according to the various values of plasma 25(OH) D by age and sex* } \\
\hline & $\begin{array}{l}\text { Plasma } 25(\mathrm{OH}) \text { D value } \\
\text { Deficient: } \leq 27.5 \mathrm{nmolL} \\
\text { Boys } \\
\text { Girls } \\
\mathrm{P}^{+}\end{array}$ & $\begin{array}{l}10 \text { years } \\
2.1(0.5-3.8) \\
2.1(0.3-4.1) \\
\text { NS }\end{array}$ & $\begin{array}{l}15 \text { years } \\
4.0(1.1-7.2) \\
8.5(5.2-14.3) \\
0.022\end{array}$ & $\begin{array}{l}\text { 20years } \\
13.2(8.5-19.2) \\
11.7(5.3-14.9) \\
\text { NS }\end{array}$ & $\begin{array}{l}P * * \\
<0.001 \\
\approx 0.001\end{array}$ \\
\hline & $\begin{array}{l}\text { Hypovitaminosis: } \square \mathbf{3 7 . 5 n m o} \\
\text { Boys } \\
\text { Girls } \\
\mathrm{P}^{+}\end{array}$ & $\begin{array}{l}6.9(3.9-11.7) \\
12.6(7.8-19.5) \\
\text { NS }\end{array}$ & $\begin{array}{l}24.9(18.5-30.8) \\
33.7(26.7-42.1) \\
0.018\end{array}$ & $\begin{array}{l}36.7(32.1-41.8) \\
30.1(22.8-34.9) \\
0.012\end{array}$ & $\begin{array}{l}<0.0001 \\
=0.0001\end{array}$ \\
\hline & $\begin{array}{l}\text { Suboptimal: } \square 75 \mathrm{nmol} / \mathrm{L} \\
\text { Boys } \\
\text { Girls } \\
\mathrm{P}^{+}\end{array}$ & $\begin{array}{l}98.1(95.1-99.6) \\
98.9(95.7-99.6) \\
\text { NS }\end{array}$ & $\begin{array}{l}99.5(98.1-100) \\
99.6(96.7-100) \\
\text { NS }\end{array}$ & $\begin{array}{l}98.6(96.9-99.9) \\
92.9(90.1-96.2) \\
0.003\end{array}$ & $\begin{array}{l}\text { NS } \\
0.004\end{array}$ \\
\hline Note: & $\begin{array}{ll}* \quad \text { Data are } \%(95 \% \mathrm{CI}) \\
* * \quad \text { Differences across ages } \\
+\quad \text { Differences between sexes } \\
\text { NS }=\text { Not significant }(\mathrm{P} \geq 0.05)\end{array}$ & & & & \\
\hline
\end{tabular}

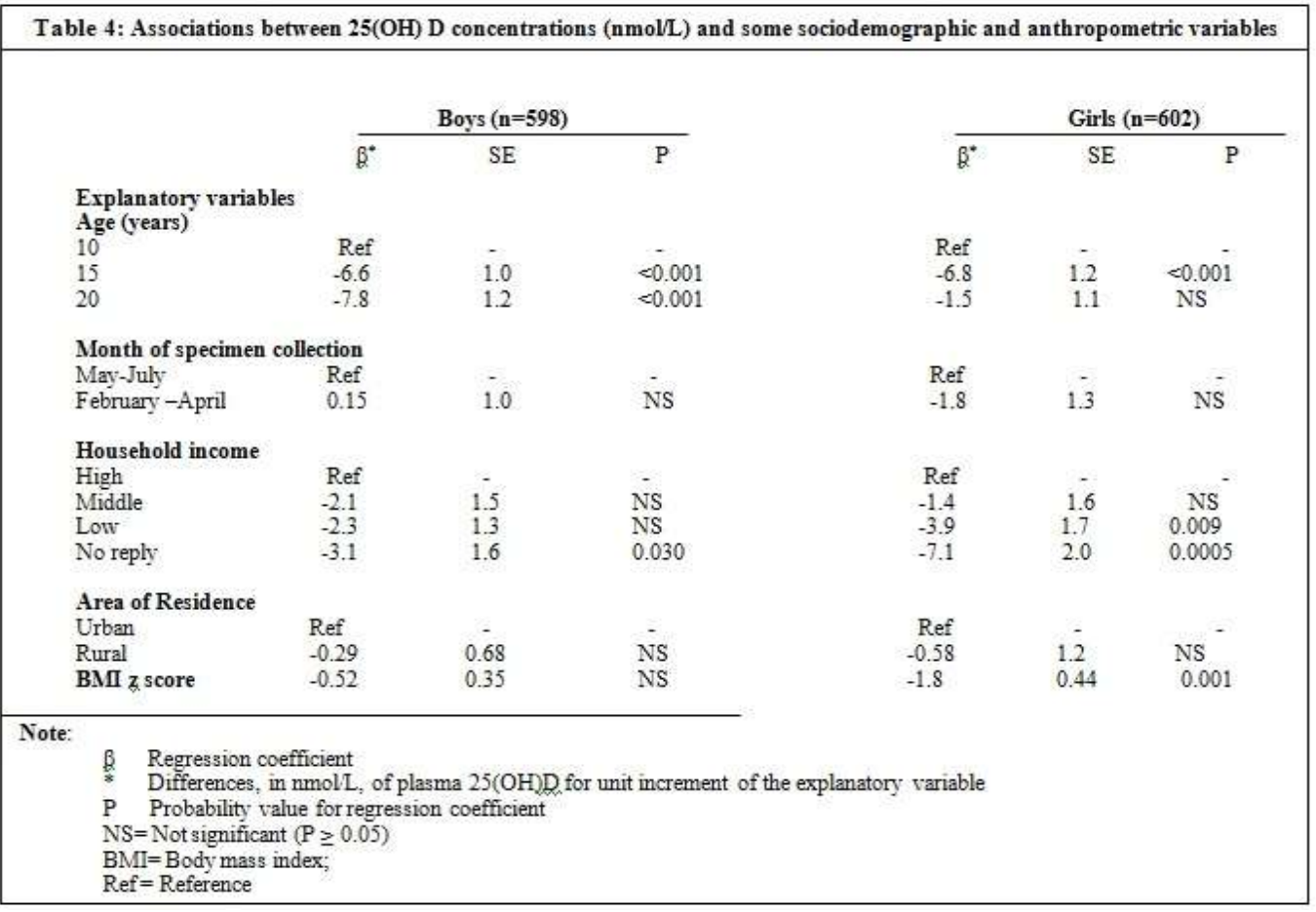




\section{References}

[1]. M. R. Haussler, J. F. Myrtle, A. W. Norman. The association of a metabolite of vitamin $\mathrm{D}_{3}$ with intestinal mucosa chromatin in vivo.J BiolChem 243, 1968, 4055-4064.

[2]. A. Prentice, I. Schoenmakers, M. A. Laskey, S. de Bono, F. Ginty, G. R. Goldberg. Nutrition and bone growth and development. ProcNutrSoc 65, 2006, 348-360.

[3]. M. F. Holick. The vitamin D epidemic and its health consequences.J Nutr 135, 2005, 2739S-2748S.

[4]. J. M. Lappe, D. Travers-Gustafson, K. M. Davis, R. R. Reckar, R. P. Heaney. Vitamin D and calcium supplementation reduces cancer risk: results of a randomized trial. Am J ClinNutr 85, 2007, 1586-1591.

[5] M. T. Cantorna, Y. Zhu, M. Froicu, A. Wittke. Vitamin D status, 1,25-dihydroxyvitamin $\mathrm{D}_{3}$, and the immune system. Am $J$ ClinNurtr 80, 2004, 1717S-1720S

[6] U. Zeitz, K. Weber, D. W. Soegiarto, E. Wolf, R. Balling, R. G. Erben. Impaired insulin secretory capacity in mice lacking a functional vitamin D receptor.FASEB J 17, 2003, 509-511.

[7] M. F. Holick. Vitamin D.A millennium perspective.J Cell Biochem 88, 2003, 296-307.

[8] M. F. Holick. Sunlight and vitamin D for bone health and prevention of autoimmune diseases, cancers and cardiovascular disease.Am J ClinNutr 80, 2004, 1678S-1688S

[9] A. R. Webb, M. F. Holick. The role of sunlight in the cutaneous production of vitamin $\mathrm{D}_{3}$. Annu Rev Nutr 8, 1988, 375-399.

[10] C. M. Weaver, J. C. Fleet. Vitamin D requirements: current and future. Am J ClinNutr 80, 2004, 1735S-1739S.

[11] M. C. Chapuy, M. E. Arlot, F. Duboeuf, J. Brun, B. Crouzet, S. Arnaud, et al. Vitamin $\mathrm{D}_{3}$ and calcium to prevent hip fracture in the elderly women. $N$ Engl J Med 327, 1992, 1637-1642.

[12] J. Guillemant, P. Taupin, H. T. Le, N. Taright, A. Allemandou, G. Peres, S. Guillemant. Vitamin D status during puberty in French healthy male adolescents. OsteoporosInt 10, 1999, 222-225.

[13] S. S. Sullivan, C. J. Rosen, W. A. Halteman, T. C. Chen, M. F. Holick. Adolescent girls in Maine are at risk for vitamin D insufficiency. J Am Diet Assoc 105, 2005, 971-974.

[14] G. Das, S. Crocombe, M. McGrath, J. L. Berry, M. Z. Mughal. Hypovitaminosis D among healthy adolescent girls attending an inner city school.Arch Dis Child 91, 2006, 569-572.

[15] G. El-Hajj Fuleihan, M. Nabulsi, M. Choucair, M. Salamoun, C. Hajj Shahine, A. Kizirian, R. Tannous.Hypovitaminosis D in healthy school children.Pediatrics 107, 2007, E53.

[16] M. S. Calvo, S. J. Whiting, C. N. Barton. Vitamin D intake: a global perspective of current status. J Nutr 135, 2005, 310-316.

[17] R. Vieth, H. Bischoff-Ferrari, B. J. Boucher, B. Dawson-Hughes, C. F. Garland, R. P. Heaney, et al. The urgent need to recommend an intake of vitamin D that is effective. Am J ClinNutr 85, 2007, 649-650.

[18] R. J. Kucmarski, C. L. Ogden, L. M. Grummer-Strawn, K. M. Flegal, S. S. Guo, R. Wei, et al. CDC growth charts: United States. Adv Data 2000: 1-27.

[19] B. Hollis. Detection of vitamin D and its major metabolites. In: D. D. Feldman, F. H. Glorieux, J. W. Pike (eds). Vitamin D (New York: Academic Press, 1997) 587-606.

[20] B. Hollis. Comparison of commercially available ${ }^{125}$ I-based RIA methods for determination of circulating 25 -hydroxyvitamin D. ClinChem 46, 2000, 1657-1661.

[21] J. M. Pettifor. Nutritional rickets: deficiency of vitamin D, calcium, or both? Am J ClinNutr 80, 2004, 1725S-1729S

[22] Institute of Medicine Food and Nutrition Board: Standing Committee on the Scientific Evaluation of Dietary Reference Intakes. Dietary reference intakes for calcium, phosphorus, magnesium, vitamin D and fluoride. (Washington DC: National Academy Press 1997), 250-287.

[23] S. Nesby-O’Dell, K. S. Scanlon, M. E. Cogswell, C. Gillespie, B. W. Hollis, A. C. Looker, et al. Hypovitaminosis D prevalence and determinants among African American and White women of reproductive age: Third National Health and Nutrition Examination Survey, 1988-1994. Am J ClinNutr 76, 2002, 187-192.

[24] B. Dawson-Hughes, R. P. Heaney, M. F. Holick, P. Lips, P. J. Meunier, R. Vieth. Estimates of optimal vitamin D status.OsteoporosInt 16, 2005, 713-716.

[25] H. A. Bischoff-Ferrari, E. Giovannucci, W. C. Willet, T. Dietrich, B. Dawson-Hughes.Estimation of optimal serum concentrations of 25-hydoxyvitamin D for multiple health outcomes.Am J ClinNutr 84, 2006, 18-28.

[26] CDC 2000 CDC Growth Charts: United States. http://www.cdc.gov/growcharts/ (Accessed January, 2008)

[27] A. Hutson. Calculating nonparametric confidence intervals for quantities using fractional order statistics.J Appl Stat 26, 1999, 343353.

[28] C. Clopper, S. Pearson. The use of confidence or fiducial limits illustrated in the case of the binomial. Biometrika 26, 1934, 404413.

[29] R. Andersen, C. Molgaard, L. T. Skovgaard, C. Brot, K. D. Cashman, E. Chabros, et al. Teenage girls and elderly women living in Northern Europe have low winter vitamin D status. Eur J ClinNutr 59, 2005, 533-541.

[30] F. L. Weng, J. Shults, M. B. Leonard, V. A. Stallings, B. S. Zemel. Risk factors for low serum 25-hydroxyvitamin D concentrations in otherwise healthy children and adolescents.Am J ClinNutr 86, 2007, 150-158.

[31] J. E. Rockell, T. J. Green, C. M. Skeaff, S. J. Whiting, R. W. Taylor, S. M. Williams, et al. Season and ethnicity are determinants of serum 25-hydroxyvitamin D concentrations in New Zealand children aged 5-14y. J Nutr 135, 2005, 2602-2608.

[32] L. M. Ward, I. Gaboury, M. Ladhani, S. Zlotkin. Vitamin D-deficiency rickets among children in Canada.CMAJ 177, 2007, 161166.

[33] M. K. Lehtonen-Veromaa, T. T. Mottonen, I. O. Nuotio, K. M. Irjala, A. E. Leino, J. S. Viikari. Vitamin D and attainment of peak bone mass among peripubertal Finnish girls. A 3 -y prospective study.Am J ClinNutr 76, 2002, 1446-1453.

[34] E. Hypponen, E. Laara, A. Reunanen, M. R. Jarvelin, S. M. Virtanem. Intake of vitamin D and risk of type 1 diabetes: a birth-cohort study. Lancet 358, 2001, 1500-1503.

[35] C. Mathieu, C. Gysemans, A. Giulietti, R. Bouillon. Vitamin D and diabetes.Diabetologia 48, $2005,1247-1227$.

[36] J. Wortsman, L. Y. Matsuoka, T. C. Chen, Z. Lu, M. F. Holick. Decreased bioavailability of vitamin D in obesity.Am J ClinNutr 72, $2000,690-693$

[37] G. Turrel. Income non-reporting: implications for health inequalities research. J Epidemiol Community health 54, 2000, 207-214.

[38] D. M. Antoniucci, D. M. Black, D. E. Sellmeyer. Serum 25-hydroxyvitamin D is unaffected by multiple freeze-thaw cycles. ClinChem 51, 2005, 258-261. 